\title{
Redesigning Legal Environment Through Environment Education Relating to The Right to Get Fresh Water
}

\author{
Winda Wijayanti ${ }^{1}$ \\ \{agnes.winda82@gmail.com ${ }^{1}$ \} \\ ${ }^{1}$ Research Center and Case Examination, and Library Management of Department, \\ The Constitutional Court of Indonesia, Jakarta, Indonesia
}

\begin{abstract}
Everything in the world needs water. The fulfilment of water is one of the human rights guaranteed by the state in the constitution. The state has to manage it with all benefits. Indonesia becomes a target from another country for importing waste is hazardous to water. There is no implementation of regulation and the sanctions for water polluters are too light. This paper to examine the legislation for redesigning the legal environment and the right to get fresh water for all benefits. This research finding are: (1) harmonize the legal environment through education can develop an awareness, and (2) make the implementation of regulation are an essential role based on the community participation and local wisdom in redesigning the legal environment to get fresh water for the maximum people's prosperity. It can also preserve the environment, especially fresh water.
\end{abstract}

Keywords: Legal environment, Environment education, The right to get fresh water.

\section{Introduction}

Everyone needs water as one of the body's nutrients, that the balance through thirst [1], so they can't live without it. Water is a common heritage of all humankind which used on to the current generation, and then use it sustainably to future generations. The human body consists mostly of fluid, so compliance of water as a life necessity and very important [2]. Getting fresh water becomes a problem by imports of plastic waste in several regions in Indonesia, such as Gresik, East Java, which are plastic chips mixed with paper that cannot be recycled. Based on the facts found by Ecological Observations and Conservation of Wetlands (ECOTON) in one paper company that investigated 11.11 percent of important materials containing plastics which reached 60 percent [3]. Valuable violations of waste often occur. Waste is imported from abroad contains plastic, metal, household waste, or other associated materials [4].

Based on Central Statistics, an increase in Indonesia's plastic waste imports by 283.152 tons in 2018. The highest peak in the last ten years, while Indonesia's plastic waste imports in 2013 were around 124.433 tons. Waste from developed countries flooded Southeast Asian countries, including Indonesia. Imports of plastic waste into Malaysia tripled in 2016 to 870.000 tons last year. The increase in the number of waste imports in 2018 will reach almost 50 percent in a year in Indonesia. Malaysia has re-exported 3000 tons of plastic waste to the country of origin of the waste. Philippines since 2013 has sent 200 containers of trash back, and Indonesia has decided to export five containers of waste from East Java to the country of origin. The rules 
on imported waste are Act Number 18 the Year 2008 on Waste Management and Trade's Ministry Regulation Number 92 the Year 2019 on Trade Minister's Regulation Amendments Number 84 Year 2019 on the Hazardous Import and Toxic Wastes as Industrial Raw Material's Provision. The two rules are already strong enough to restrain the waste import, but it is just being monitored so as not to pollute the environment. The rules in the form of a prohibition to put waste into the territory of Indonesia, mixing waste with hazardous and toxic waste, and managing waste cause pollution and/or environmental damage as mandated by act because of water pollution is unfinished [5].

Indonesia is one of the center world's marine ecosystems. Coral species, seagrass beds, and mangrove forests stay in the waters. Various species of fisheries will be disturbed by the presence of plastic waste. Many plastic waste in 2010 from worldwide were wasted and polluted the sea. Indonesia has a coastal population of 187.2 million which annually produces 3.22 million tons of plastic waste that appropriately organized and the oceans contaminate by the plastic waste. Based on Indonesia's land and sea pollution due to plastic waste, if import waste does not immediately stop and plastic waste cannot take care precisely, it will further damage fresh water. Local communities become the origin of development and implementation programs that tackle issues of climate change and sustainability. Elaborating environmental awareness is important during childhood and formal education in the school. Partnerships between communities and schools have the potential for acquiring more transformative change, through more authentic learning experiences for the local surroundings [6]. Importing plastic waste and being able to collect waste that can be organized properly will increase fresh water will transfer everyone's right to get fresh water can protect human health, especially for the future. Redesigning the legal environment through environmental education and the right to get fresh water for all benefits as a crucial result in the future. The increasing amount of waste can damage fresh water, but the regulations do not support the community in the use of fresh water for public purposes equally.

\section{Method}

This paper uses Ramsey and Rickson's perspective that knowledge enhancement through education is encouraging environmental quality. Regulating and implementing the environment education based on local wisdom and the right to get fresh water for all benefits as a state of duty. The aim of the research is redesigning the legal environment through harmonize the regulation with a combination environment of formal education, local wisdom, and evaluate the right to get fresh water. This research uses the regulation about environmental protection and management, water resources, health, and education and make comparison with Malaysia in sanction for water polluter as redesign legal environment.

\section{Result and Discussion}

Pollution in water is the presence of objects that cause the water cannot be used abnormally for specific purposes. For example, drinking water (piped water, decent water), swimming/recreation (swimming pool, seawater on the beach), bathing (water plumbing, propitious water), aquatic animal life (river water, lake water), irrigation and industrial uses containing certain foreign substances over the limit [7]. Water pollution is vulnerable that cause 
environmental harm. Moreover, pollution in childhood can have an impact continously, include cancer [8]. The right to get fresh water is a primary human need for health and prosperity that must be protected by the state.

\subsection{Redesigning Legal Environment through Environment Education}

The importance of environmental education can be explored through local wisdom, just as Malaysia has managed peat resources sustainably through compaction and water management. Decent communication will build community awareness and correct erroneous assumptions about peatlands and peat fires. Peat can be managed well in Malaysia, so it is difficult to burn, namely, Sarawak is the largest peat area with 1.6 million hectares of peatland or 13 percent of the land area can be protected from fire because it has good compaction technology and water management starting from small farmers to large corporations. Awareness of technology is important. It should be communicated by academics to stakeholders through the socialization of scientific studies to manage peat so that the issue of peat fires not will happen in Central Kalimantan. Good water management can maintain peatland moisture and maintain existing water reserves. Indonesia has 15 million hectares of peat, 4 million are used for production, 4 million hectares are degraded, and 2 million hectares in the form of shrubs and the remainder is forest. Peat areas are still forested should be left, but degraded peat or scrub can be conserved as suitable as agricultural land or production forest [9].

When the management of water resources is associated with local wisdom, then the management must concentrate to the noble values that apply in the way of life of the community (Article 2 letter $\mathrm{f}$ of Act Number 17 Year 2019 on Water Resources) to among others protect and manage the sustainable in environment. Article 2 letter f Act Number 17 Year 2019 states "Water Resources Management is carried out based on the principle: $f$. local culture;". Love the environment can create and preserve the existence of water is fit for human consumption through environmental education by making the best use of water. Utilization of the environment around humans based on local wisdom properly and sustainably can preserve the existence of water. It can be utilized as well as possible in human life.

The aim of water resources regulation aims to provide protection and guarantee the fulfilment of people's rights to water, the sustainability of the water and the resources to provide fair benefits for the community, the water preservation and the function to support sustainable development, ensure the creation of legal certainty for the community participation in supervising the use of water resources, from planning, implementing, and evaluating utilization, ensuring the protection and empowerment community, including indigenous peoples in efforts to conserve water resources, utilize water resources, and control the destructive of water. The role of indigenous peoples is very important to be involved in the management of water resources for sustainability. The government must also concern about that for sustainability based on harmonizing regulation through Article 6 paragraph (1) letter $\mathrm{f}$ Act Number 1 the Year 1967 on Outside Investment that states "Closed Business Fields for foreign investment in full control are the fields that are important to the country and control the livelihoods of the people as follows: $f$. drinking water;" and Article 5 Water Resources Act that "Water Resources are controlled by the state and used for the greatest prosperity of the people." Water resources management has endeavoured for steady development as a conscious and planned effort to ensure environmental integrity and the security, proficiency, prosperity, and the life's grade of present and future (Article 1 Number 3 Act Number 32 the Year 2009 on the Environmental Shelter and Supervision). The provisions are aimed at legal certainty and protection for everyone to get a good environment. 
The education about environment as a right for everyone (Article 65 paragraph (2) Act Number 32 the Year 2009) that "Everyone has the right to achieve environmental education, access to information, access to participation, and access to justice in fulfilling the right to the environment." Education about environmental is part of the effort to secure and manage nature as the duties and Government's authorities (Article 63 paragraph (1) letter w Act Number 32 Year 2009 reads "In environmental protection and management, the Government has the duty and authority of : w. provide education, training, coaching, and appreciation;". The right to environmental education for Indonesian that creates an obligation for the Government to carry out such education. The sanctions are not regulated in Act Number 32 Year 2009. Environmental care that stems from a love for the surrounding must be sharpened early on through education.

The Environmental Act has educational arrangements, but there is only an education system that introduces students to the new curriculum. Society is not easy to have awareness about the environment. The desire to secure the environment will be minimal when the effort is not carried out early. One person starts from small things by preserving mangroves on the coast of Indonesia. One example, the famous coast of Indonesia is mangrove forest in Indramayu, West Java, namely Karangsong. There were already groups that had environmental concerns there, even though they had not yet brought maximum impact. Mangroves have an important role in community life around the coast. Therefore, its sustainability must be maintained so that children and grandchildren can feel the benefits. It is one of the efforts to create a generation of environmental awareness will be the perpetrator and guardian of sustainable development in the future. The most effective character building is the formal education system at elementary school-age children.

The teacher is also involved in forming education. The curriculum is expected to produce young people to have more love and commitment to preserving the environment, especially mangroves. Development agencies will be formed with environmental insight in the future. The environment love makes the legislators and organizers in creating the Environmental Act truly love the environment. Preserving plants that become local wisdom. For example, Japan maintain healthy oceans to improve the capability to cope with climate change in the island. They supporting for coastal protection by utilizing ecosystems like coral reefs and mangroves and contributing to the water stock's development sector [10]. Whereas in Indonesia, tall buildings in urban areas and more buildings with glass, for example, Jakarta, no longer pay attention to the negative impacts or effects of greenhouses that reduce ozone (CFC). Policymakers and licensors will be wiser to love the environment for taking and issuing policies carefully that concern the lives of many people.

Mangrove's education can have good character and knowledge about the environment for children. If there is love and ownership, it can raise a good skill in preserve mangrove forests. Practically, Mangrove-related education has been started since 2016 [11]. A nation is strong, rich, and culturally diverse like China when they can preserve traditions based on history and cultural interactions between art, literature, beliefs, and religion as national consciousness that makes flora and animal survival. Inheritance of tradition from adults to children fosters morals into everyday life including respect for the environment. It is an important component of environmental education for young people [12].

The rights are used for protection the environment are continually evolving. A "right" to the "environment," the adjectival objective "fresh" or "healthful" or "quality" differs from state to state. For example, Hawai'i's and Montana's constitutions aim to afford a "fresh and healthful environment," Illinois' "a right to a healthful environment," Massachusetts' a "right to fresh air and water, freedom from excessive and unnecessary noise, and the natural, scenic, historic, and 
esthetic qualities of their environment," and Pennsylvania's" a right to fresh air, pure water, and to the preservation of the natural, scenic, historic and esthetic values of the environment." Some of these provisions may overlap with nuisance laws or other codes, such as city and local ordinances that limit noise or protect property owners' access to light and air or access to public amenities such as beaches, but the constitutional provisions tend to be much broader in scope and richer in values, that the codes tend toward more precise standard-setting [13].

Education has the prior aim that is shaping human behavior. Societies with the world establish educational systems to develop citizens who will behave in many ways. In education, some of the desired behaviors are sharply defined, like skills to mathematics and reading. Their research about the effectiveness of environmental education for promoting responsible citizen behavior. Based on Tbilibisi conference declaration about environmental education that: awareness and sensitivity to the total environment allied problems; sensitivity gains a variety of experience acquire a basic understanding the environment and the problems; attitudes acquire a set of values and feelings of concern for the environment and motivation for actively participate in environmental improvement and protection; skills know and solve environmental problems; and participation is an opportunity to be actively involved at all levels in working toward environmental problem's resolution. If environmental problems become an integral part of instruction designed to change behavior, instruction must go beyond an "awareness" or "knowledge" of issues. Students promote a sense of "ownership" and "empowerment" are fully invested in an environmental sense and become responsible.

Awareness comes from sense or feeling, but knowledge comes from study or education or a way that get from studying. It can say that awareness and knowledge are two things that are different, but connecting each other. The human can get knowledge from education, and then they get awareness about something from education. In line with Ramsey and Rickson, knowledge enhancement through education directs to pleasant demeanors, that advances environmental quality [14].

The rules of environmental law and the national education system have been harmonized about the education about environmental in the curriculum (formal education), but sanctions for violations or disobedience to the rules of organizing education to the government do not yet exist or are uncompleted norms. Schools that have been conducting environmental education based on local wisdom, not the government. The absence of sanctions for government obligations also makes this norm ineffective or futile. The government through the community can empower or develop the community to form a social environment that loves its environment based on local wisdom. Previously when the parties that would carry out activities or businesses that could cause pollution and environmental damage, it was these social institutions or communities that had advanced first with the assistance and coordination of the local government to secure environment based on a love for the environment. Environmental education can not be effective also appears from the absence of regulations under the Act, so that the provisions are broken off related to the organizers of education, facilities and infrastructure, curriculum types and curriculum objectives, teachers and their roles, etc., the need for further regulation on environmental education through a joint regulation.

Ethics are formed from the social environment of the community as a guide for the community and the government to act on the environment.e presence of ethics builds awareness of a fresh and healthy environment that produces quality water for human life. Ethics so that it can be lived and implemented in people's lives requires law as a way to secure the environment. Society and government through the law together to fight for the environment, when education and the environment whose implementation cannot be forced through legal instruments [15]. The rule of law is important to have strict sanctions so that their implementation is effective. 
No matter how severe the sanction of fines as the last legal remedy to expose violators as a substitute for environmental damage, if not accompanied by awareness to love the environment from the community and the government through environmental education, the existence of environmental laws is in vain. This situation automatically makes the community more and more already getting quality water to meet the needs of people's lives that have an impact on violations of the rights of the community and its future generations for a better life.

Uncompleted norm because there is no further regulation of the provisions of environmental education, for example compiling regulations with the Environment Minister with the Education and Culture Minister (the organizers, who are educated, the form of education (curriculum), the authorities to teach, etc.) which aims to build a sense of love for the environment for its survival. The sanctions is also a paradigm for redesigning environmental education settings based on local wisdom. This is important to be carried out together with the strengthening of social institutions by emphasizing sanctions for the presence of the environmental destroyer to restore environmental damage.

Executing environmental strategies and programs in Malaysia that use the five-year plans within the legal and institutional framework. The results of Agenda 21 and sustainable development were incorporated and integrated into the national planning process. Criminal sanctions for environmental offenses in Malaysia under statute law are in the form of fines and jail sentences for serious cases. The death penalty may be inflicted in very serious cases. For example, under the Act 2006 about Water Industry Services, the commission of the offense of contamination of water, a person who is found guilty of contaminating any watercourse with any substance to cause death. The death or imprisonment may extend to twenty years as punishment, and the punishment is not death, he shall also be liable to whipping (Section 121 Act 2006, Water Industry Services).

Basic principles of environmental law in Malaysia, there is no specific provision in the Federal Constitution which speaks about the recognition or protection of the public's right to a healthful environment. Consequently, Malaysia's approach to environmental management through policy and legal measures has not evolved from a Constitutional mandate to afford the public a right to get fresh air, water, and environment. According to Act 127, 1974 (Environmental Quality), penalties provided include a fine, or imprisonment, or a combination. For more serious offenses, the court may even impose the death sentence on the accused person. In Malaysia, the death penalty is the most severe punishment that can be imposed on a person and this penalty can be found under section 121 of the Water Industry Services Act 2006 for the offense of contamination of water. Under section 121 (2), a guilty person of an offense under subsection (1), on conviction, death is the result of the act, shall be punished with death or imprisonment for a term may extend to twenty years. If the punishment is not death, he shall also be knouting.

Modern environmental legislation in Malaysia represents the government's policy in using criminal sanction as a deterrence measure in criminal related offenses. The death penalty, the longer period of imprisonment, the introduction of whipping, and the imposition of higher amounts as penalties for environmental offenses, reveal that harsh punishments in result to decrease of crimes against the environment, regardless of the actual effectiveness of this policy in securing the environment [16]. In contradiction about the sanction for the water polluters, Indonesia has "the polluter must be pay" principle in legal environment (Article 87 paragraph (1) Act Number 32 Year 2009). Sanctions for environmental pollutants are too light that a maximum sentence of 15 years imprisonment and a maximum fine of 15 billion rupiah (Article 98 paragraph (3) Act Number 32 Year 2009), when the actions result in serious injury or death to others or the same sanctions when people enter hazardous and toxic material waste to 
Indonesia's territory (Article 106 paragraph (3) Act Number 32 Year 2009). Sanctions that are not proportional to the impact of pollution are not under the soul and spirit of the formation of environmental law, namely the state through the government must protect and manage the environment for sustainable implementation so that it remains a source and support of life for the people of Indonesia and other living things (General Explanation Act Number 32 Year 2009). Considering that water is the most important and sustainable necessity of human life and living things cannot live without water, sanctions for water pollutants should be very severe. Imposing sanctions that are not proportional to the effects of water pollution caused by environmental pollutants will cause environmental laws to be ineffective and futile. The imposition of very severe sanctions for water pollutants as acts that violate human rights to good and healthy environmental rights in Article $28 \mathrm{H}$ paragraph (1) of the 1945 Constitution and have enormous impacts and losses to prevent water pollution, deterrent, and protect human rights. Therefore, designing of legal environment changes immediately to the more severe sanctions in the form of capital punishment or life imprisonment and the imposition of fines according to the calculation of the worst impacts due to pollution in legal environment.

Regulation on the precise role of government to environmental management policy. The reconstruction of systems of environmental governance to ensure sustainable development is a serious challenge [17]. Environmental education through redesign of the rule-based on local wisdom must be carried out on an ongoing basis so that the implementation is effective on the environment. Affection environment to formal education on local wisdom for generations, but there is no sanction becomes a problem. The important role of community institutions based on local wisdom who destroy the environment must participate directly in restoration, and not based on sanctions and fines. The strengthening and preservation of local culture to produce fresh water in areas are very useful for the consumption, swimming pool, industry, tourist arena, and finally to Bali's economy. For example, Subak namely irrigating rice fields in social, technological, and religious at Hindu society [18] can be developed to obtain fresh water by removing waste that can damage the natural beauty, ecosystem, and the health of vicinity, accompanied by environmental education giving rise taste and attitude to not have the heart and love the surrounding environment.

According to Hans Kelsen, the characteristic of positive law is a coercive order, which is an order that forces it as one form of sanctions including seizure by force out of will affected by everything possessed by humans such as life, freedom, or property. Sanctions in the form of punishment and reward. Pospisil stated that the inclusion of sanctions was needed in statutory regulation. The purpose of sanctions so that the law toothed. When the rule of law in the form of an order (obligation) or prohibition will be an empty order or guarantee and tends not to be obeyed if there is no sanction attached. The rule of law (legal norms) containing the contents (gebod) [19] is an order to carry out something through the words "mandatory" or "must".

Related to the provision that every education in Indonesia must have an environmental education, but the regulations under it do not emphasize the involvement of local wisdom to include local communities and the noble heritage of their ancestors as a basis for environmental preservation. Local wisdom has also been regulated in Article 36 paragraph (3) Act Number 20 Year 2003 on National Education System stating "The curriculum is prepared by the level of education within the edging of the Unitary State of the Republic of Indonesia by taking into account: $d$. diversity of regional and environmental potential." An environment that best knows the situation is the people themselves. The requirement of regulations harmonization so the implementation is effective and its sanctions. In the absence of sanctions for one's obligations, include the sanctions are too light is cause the law will be useless and ineffective. 


\subsection{The Right to Get Fresh Water for All Benefits}

Healthy water is water that can be consumed, as regulated in Article 1 Number 5 Water Resources Act, that drinking water is water that is processed or not to health requisited and can be taken immediately. Article 162 Act Number 36 Year 2009 on Health that "Environmental health efforts are aimed at realizing a healthy environmental quality, be it physical, chemical, biological, or social which enables everyone to achieve the highest degree of health." Water that is healthy and does not have bad risks to health includes contaminated liquid waste, solid waste, waste gas, waste that is not processed under government requirements, disease-carrying animals, hazardous chemicals, ionizing and non-ionizing radiation, water polluted (Article 163 paragraph (3) Act Number 36 the Year 2009).

Malgosia Fitzmaurice thinks based on Jonna Razzaque's experiment that the humans are consumed only 10 percent of annual world water stock and only 15 percent have a water's galore. World Resources Institute (WRI) also says that the world face called "water stress". It means that many people will drink water that does not have access a well sanitation in resulting sanity matters [20]. Nowadays, in Indonesia importing waste will certainly affect water quality which will have an impact on the health of the surrounding community.

United Nations Development Programme (UNDP) Human Development Report in 2006, which states that rule is critical to the progressive realization of the human right to water and shelter of public interest in provision's water. Based on that, water privatization in constitution for the greatest people's prosperity. When the country can not produce fresh water, it can manage third parties with competition for prosperity, suitability or appropriateness and efficiency.

The right to water is known in international law and regional human rights systems as a fully independent human right. It is a derivative right or in a fragmented fashion in several treaties. For example, Article 36 the Constitution of Fiji (2013) requires the state to 'take reasonable standart within its available resources to gain the progressive realization of the right of every one to be free from hunger to have adequate food of acceptable quality and to fresh and safe water in adequate quantities'. Then, the right to access to water in India has been read into the right to life. Article $28 \mathrm{H}$ the 1945 Constitution provides that every one has the right to live in physical and spiritual prosperity, to enjoy a home and a well environment.

Based on the 1945 Constitution, everyone has the right to a good and healthy environment is regulated in Act Number 36 Year 2009 on Health. It is a basis for government to realize the rights of Indonesian citizens will be elaborated by the regulations below. For example, Article 6 Water Resources Act states "The state guarantees the people's right to use water fulfill the minimum daily basic needs for a healthy and fresh life with sufficient quantity, good quality, safe, sustainable, and affordable." Environmental conditions are important to know the implementation is easy and can develop the right environment paradigm for the future. The management of water resources must be related to constitution. It is managed by the state and used to the greatest people's welfare. It can not be owned and/or controlled by individuals, community groups, or business entities (Article 7 Water Resources Act).

The United Nations members were adopted the Sustainable Development Goals (SDGs), so water becomes one of the main agendas in 2015. The aim of water to "ensure availability and sustainable management of water and sanitation for all." Target 6.1 of Goal 6 estimates that "by 2030, achieve universal and equitable access to safe and affordable drinking water for all." [21].

The 1945 Constitution of Indonesia has amended four times in 1999, 2000, 2001, and 2002 [22]. The right to fresh water as part of the constitutional rights that guaranteed by Article 33 
paragraph (3) states" The earth and water and the natural resources are controlled by the state and are used for the greatest prosperity of the people.", namely water is controlled by the state and used for the people's maximum prosperity. Article $28 \mathrm{H}$ paragraph (1) in the Indonesia's highest law is the basis for securing the constitutional rights to obtain a good environment through the acquisition of the right to fresh water, without the presence of hazardous and toxic waste that can damage water quality.

One of the most important and fundamental elements in human living is water, so the control over the lives of many people is carried out by the state is the meaning of "earth and water and the wealth of natures are controlled by the state and used for the greatest prosperity people". For the preservation and sustainability of availability will be water, there are five very strict limits for the utilization of water, namely: (1) should not interfere, override, and negate the people's right to water; (2) the state must fulfill the people's right to water which has the right to access water as a human right; (3) fulfillment of human rights to environmental sustainability; (4) state supervision and control over water is absolute; (5) the main priority of exploitation of water is given to State-Owned Enterprises or Regional-Owned Enterprises [23]. The right to get water, including the right to obtain fresh water, must be respected, protected and fulfilled by the state as one of the living rights that must be preserved and not only related to the current needs of life but also the future related to human existence. The Constitutional Court of Indonesia in its decision also recognizes the customary rights of indigenous and tribal peoples who still live on the water resources under Article 18B paragraph (2) the 1945 Constitution [24]. The use of water as all benefit must be limited, namely meeting daily basic needs, smallholder agriculture, and non-business activities for the maximum prosperity of all people in all regions of Indonesia evenly and controlled by the state, so the right to use in water must involve community participation in the management of water resources.

Local wisdom is a legacy of noble values for generations. It preserves the environment creates education for future generations which is only regulated in Act Number 17 the Year 2019. There are obligations in legal environmental to maintain the preservation of environmental functions and control pollution and/or environmental damage, including the acquisition of fresh water, must be accompanied by the acquisition of the right of the public on environmental education is formally based on local wisdom to create a love for the environment and access to water use fresh evenly and "controlled by the state" with the participation of the public the widest on access to water. Management fresh water by the state is a benefit for the greatest community prosperity. Harmonizing Act Number 32 Year 2009, Act Number 36 Year 2009, Act Number 17 Year 2019, and Act Number 20 Year 2003) is very important with environmental education and local wisdom. The need for implementation of Act Number 17 Year 2019 in the form of Government Regulations as committed to water resources in Article 78 Act Number 17 Year 2019 and make the local of regulations that harmonize environmental education and the curriculum by local wisdom. The right to formal environmental education is one of the community engagements by students to maintain the existence of water as part of the environment and their continued survival.

\section{Conclusion}

The right to get fresh water is the main need for human health and welfare, so the state must provide the fulfillment of these rights. The state manages the water and used it for the greatest prosperity of the people so the water resources cannot be owned and/or controlled by individuals, community groups, or business entity. The water is used for as all benefit, but it 
must be limited (daily basic needs, smallholder agriculture, and non-business activities) for the maximum prosperity of people in all regions of Indonesia evenly and controlled by the state. The right to use water must involve community participation in the management of water resources for the future related to human existence. Any heavy rights and obligations will not present a deterrent or fear of polluters, if the sanctions are too light. In Malaysia, some severe sanctions for violators of environmental act and the provisions are adhered to by its people. When every community and government through its apparatus has a love for the environment through environmental education it will cause compassion and internalization for the environment for the future. Regulation is not being accompanied by sanctions will be in ineffective and futile. The designing of legal environment changes immediately to the more severe sanction (death penalty, life imprisonment, etc.) and the imposition of fines according to the calculation of the worst impacts due to pollution. The harmonization of regulation by combining environmental education and local wisdom is important. The need for implementation of Act (Government Regulations) and make the local regulations that harmonize environmental education and the curriculum by local wisdom.

\section{Acknowledgments}

This article has presented on ICILS $3^{\text {rd }} 2020$ by the Semarang State University.

\section{References}

[1] Ben-Nun, Liubov: Water and Its Role for Human Health. Israel: BN Publications House (2012)

[2] Chirwa, Danwood M., et., al.: The Cambridge Handbook of New Human Rights Recognation, Novelty, Rhetoric. Cambridge University Press (2020)

[3] Indonesian Center for Environmental Law (ICEL). "Meski Dilarang, Impor Sampah Plastik 2018 Naik 141\%." Info Singkat Pusat Penelitian Badan Keahlian Dewan Perwakilan Rakyat Republik Indonesia Vol. XI No. 12/II/Pulit/Juni/2019. https://icel.or.id/berita/meski-dilarang-impor-sampahplastik-2018-naik-141/. <Accessed 16 March 2020>

[4] Prasetiawan, Teddy: "Ancaman Impor Sampah Terhadap Indonesia". http://berkas.dpr.go.id/puslit/files/info_singkat/Info\%20Singkat-XI-12-II-P3DI-Juni-2019-223.pdf.

$<$ Accessed on 16 March 2020>

[5] Adharsyah, Taufan: "Sebegini Parah Ternyata Masalah Sampah Plastik di Indonesia". https://www.cnbcindonesia.com/lifestyle/20190721140139-33-86420/sebegini-parah-ternyatamasalah-sampah-plastik-di-indonesia. <Accessed on 16 March 2020>

[6] Flowers, Rick and Andrew Chodkiewicz: Local Communities and Schools Tackling Sustainability and Climate Change. Australian Journal of Environmental Education, Vol. 25 January 1 pp. 71-81 (2009)

[7] Fardiaz, Srikandi: Polusi Air dan Udara. Yogyakarta: Kanisius (1992)

[8] Knox, John H.: Framework Principles On Human Rights and The Environment. United Nations Human Rights Specials Procedurs (2018)

[9] Muhanda, Asep Dadan: "Terapkan Tata Kelola Air, Gambut Di Malaysia Tak Terbakar." https://ekonomi.bisnis.com/read/20151116/99/492480/javascript. <Accessed on 10 March 2020>

[10] Nakagawa, Masaharu: Statement by Masaharu Nakagawa, Minister of the Environment of Japan, at COP 23. http://www.env.go.jp/en/focus/171115.html. <Accessed on 3 February 2020>

[11] Wahyudi, Agus: "Kurikulum Pendidikan Lingkungan Hidup Mencetak Generasi Peduli Lingkungan." https://nationalgeographic.grid.id/read/131268522/kurikulum-pendidikan-lingkunganhidup-mencetak-generasi-peduli-lingkungan?page=all. <Accessed on 13 March 2020>

[12] Lee, John Chi-Kin and Michael Williams (Ed.): Schooling for Suistanable Development in Chinese Communities: Experience with Younger Children. Springer (2009) 
[13] Turner, Stephen J. et., al.: Environmental Rights The Development of Standarts. United Kingdom: Cambridge University Press (2019)

[14] Hungerford, Harold R. and Trudi L. Volk: "Changing Learner Behavior Through Environmental Education.” The Journal of Environmental Education. Vol. 21 Issue 3, pp. 257, 258, and 267 (1990)

[15] Keraf, A. Sonny: Etika Lingkungan Hidup. Jakarta: PT. Kompas Media Nusantara (2010)

[16] Mustafa, Maizatun: Environmental Law Malaysia (Fourth Edition). Wolters Klower

[17] Richardson, Benjamin J.: Environmental Regulation Through Financial Organisation: Comparative Perspectives on the Industrialised Nations (Volume 2). Wolters Kluwers (2002)

[18] Tarigan, Herlina, et. al.: "Persaingan Akses Sumber Daya Air Di Yeh Ho, Tabanan, Bali." Jurnal Agro Ekonomi. Vol. 31 No. 2 October, pp. 143 and 147 (2013)

[19] Harahap, Zairin: "Pengaturan Tentang Ketentuan Sanksi Dalam Peraturan Daerah". Jurnal Hukum. No. 1 Vol. 13 January, pp. 44 (2006)

[20] Fitzmaurice, Malgosia. "The Human Right To Water." Fordham Environmental Law Review. vol. XVIII No. 3, pp. 538, (2007)

[21] Japan International Cooperation Agency: Japan's Experiences on Water Supply Development. Japan: Water Partners Jp Co., Ltd. and Nihon Suido Consultants Co., Ltd. (2017)

[22] Nugraha, Harry Setya: "Gagasan Amandemen Ulang Undang-Undang Dasar Negara Republik Indonesia Tahun 1945.”. Lex Renaissance. No. 1 Vol 3 January, pp. 64 (2018)

[23] Decision of the Constitutional Court Number 85/PUU-XI/2013 concerning the Judicial Review of Act Number 7 Year 2004 concerning Water Resources dated February 18, 2015, p. 138-139

[24] Decision of the Constitutional Court Number 058-059-060-063 / PUU-II/2004 and 008/PUUIII/2005 concerning the Judicial Review of Act Number 7 Year 2004 concerning Water Resources dated July 19, 2005, p. 489 and 503 